Eur J Clin Chem Clin Biochem

1995; 33:553-558

(c) 1995 Walter de Gruyter \& Co.

Berlin $\cdot$ New York

\title{
Changes of Ionized Magnesium and Free Fatty Acids in Serum after Acute Myocardial Infarction
}

\author{
By Frank Bertschat ${ }^{1}$, Hartmut Ising ${ }^{2}$, Theodor Günther ${ }^{3}$, Allen Jeremias ${ }^{1}$ and Elisabeth Jeremias ${ }^{1}$ \\ ${ }^{1}$ Medizinische Klinik und Poliklinik mit Schwerpunkt Nephrologie/Intensivmedizin, Universitätsklinikum Rudolf \\ Virchow, Charlottenburg, Freie Universität Berlin, Berlin, Germany \\ 2 Institut für Wasser-, Boden- und Lufthygiene, Umweltbundesamt, Berlin, Germany \\ 3 Institut für Molekularbiologie und Biochemie, Freie Universität Berlin, Berlin, Germany
}

(Received January 12/May 29, 1995)

Summary: The most feared early complications after an acute myocardial infarction are ventricular arrhythmias. These may be initiated by changed concentrations of catecholamines and electrolytes. The present study shows a reduction of total serum magnesium after acute myocardial infarction which is normalized within a few days. Further, it could be shown that a more significant decrease of ionized $\mathrm{Mg}^{2+}\left(\mathrm{iMg}^{2+}\right)$ takes place at the day of acute myocardial infarction in the total group of myocardial infarction patients $(n=36)$. A closer investigation reveals that $\mathrm{iMg}^{2+}$ was considerably decreased in one third of the patients, whereas two thirds showed minor changes of $\mathrm{iMg}^{2+}$ in both directions. The pronounced decrease of $\mathrm{iMg}^{2+}$ in the first sub-group can be explained by the time course of free fatty acids in serum. On the day of the myocardial infarction free fatty acids in serum were increased. This is probably caused by $\beta$-adrenergic-induced lipolysis due to catecholamines released by the stressful situation of an acute myocardial infarction. The increased free fatty acids in serum bind $\mathrm{Mg}^{2+}$, thus reducing $\mathrm{iMg}^{2+}$. $\mathrm{As}$ long as a beneficial effect of a general $\mathrm{Mg}$ infusion in all acute myocardial infarction patients is controversial, $\mathrm{iMg}^{2+}$ should be measured and $\mathrm{Mg}$ infusion therapy should be applied only in patients with low $\mathrm{iMg}^{2+}$.

\section{Introduction}

Lethality after acute myocardial infarction is particularly caused by ventricular arrhythmias (1-3). Recently, several publications indicated that these early complications are initiated by changed concentrations of catecholamines and electrolytes (4-10), and possibly by increased formation of free radicals and lipid peroxidation $(11,12)$. In these mechanisms extracellular magnesium may be involved. At reduced serum $\mathrm{Mg}$ more catecholamines are released (13) and permeability of $\mathrm{Na}^{+}$and $\mathrm{K}^{+}(14)$ and lipid peroxidation is increased (15). Dyckner et al. (16) and Bigg \& Chia (17) showed that cardiac fibrillations appeared more frequently in myocardial infarction patients with low total serum Mg. Iseri et al. could even improve therapy-resistent ventricular arrythmias with $\mathrm{Mg}^{2+}$ infusions (18).
Several authors described a transient decrease of total serum magnesium during the first 24 hours after acute myocardial infarction which reached normal values 6 to 14 days later $(19-23)$. The fall of serum magnesium may be explained by increased lipolysis due to stress-induced catecholamine release. The free fatty acids bind $\mathrm{Mg}^{2+}$. Thus the free fatty acids in adipocytes reduce the concentration of intracellular free $\mathrm{Mg}^{2+}$ in these cells followed by $\mathrm{Mg}^{2+}$ uptake in adipocytes $(24,25)$. The increased free fatty acids in serum after acute myocardial infarction bind $\mathrm{Mg}^{2+}$ and consequently the concentration of free $\mathrm{Mg}^{2+}$ after acute myocardial infarction may be more reduced than total serum $\mathrm{Mg}$. Therefore, we investigated the alteration of ionized $\mathrm{Mg}^{2+}\left(\mathrm{iMg}^{2+}\right)$ in serum after acute myocardial infarction. 


\section{Materials and Methods}

Forty-two patients ( 37 men and 5 women) with an acute myocardial infarction who were admitted to the Klinikum R. Virchow, Charlottenburg, Free University Berlin in the time of July 1992 until October 1992 were examined. The average age of the patients was 62.5 years (range: $40-88$ years). The diagnosis "acute myocardial infarction" was determined by ECG, the rise of creatine kinase and the subjective pain of the patients. At days 1, 2, 3, 5 and 7 after infarction (day 1 = day of infarction) blood was taken in the moming before breakfast with a plain vacutainer. Blood was centrifuged within 60 minutes after collection, the temperature not exceeding $25^{\circ} \mathrm{C}$. $\mathrm{iMg}^{2+}$ in serum was measured with the "Microlyte Magnesium" (Kone Instr. Espoo, Finland) within 60 minutes after blood centrifugation. The deviation of $\mathrm{pH}$ and the resulting change in $\mathrm{iMg}^{2+}$ was corrected using the equation:

$$
\lg \left[\mathrm{iMg}^{2+}(\mathrm{pH})\right]=\lg \left[\mathrm{iMg}^{2+}(7.4)\right]+\mathrm{x}(7.4-\mathrm{pH}) .
$$

For $x$ a value of 0.11 was used (26). Total serum magnesium was determined by atomic absorption spectroscopy. Free fatty acids were measured with the enzymatic colour test "NEFA c" (27).

\section{Results}

Table 1 shows the mean values and standard deviations of the electrolyte concentrations and free fatty acids in serum of the patients at day 1 (day of infarction) and their changes from day 1 to day 2 . Because of missing values at day 2 the number of measurements varies between 28 and $36 . \mathrm{iMg}^{2+}$ was significantly lower at day 1 than at day 2 , whereas free fatty acids were significantly higher at day 1 than at day 2 . The

Tab. 1 Mean values and standard deviations of electrolytes and free fatty acids in blood samples of acute myocardial infarction patients at day 1 and mean differences of these analyte concentrations between day 1 and day 2 .

\begin{tabular}{|c|c|c|c|c|c|c|}
\hline \multirow[t]{3}{*}{ Analysis } & \multicolumn{2}{|l|}{ Day 1} & \multirow[t]{3}{*}{$\mathrm{n}$} & \multicolumn{2}{|c|}{ Day 2-Day 1} & \multirow{3}{*}{$\begin{array}{l}\text { Sig- } \\
\text { nifi- } \\
\text { cance }\end{array}$} \\
\hline & Mean & SD & & Mean & SD & \\
\hline & \multicolumn{2}{|l|}{$\mathrm{mmol} / \mathrm{l}$} & & \multicolumn{2}{|l|}{$\mathrm{mmol} / \mathrm{l}$} & \\
\hline $\mathrm{iMg}^{2+}$ & 0.55 & 0.07 & 36 & +0.04 & 0.07 & $* *$ \\
\hline $\mathrm{Mg}_{\text {total }}$ & 0.79 & 0.10 & 36 & +0.01 & 0.08 & n.s. \\
\hline $\mathrm{iCa}^{2+}$ & 1.15 & 0.08 & 36 & +0.02 & 0.09 & n.s. \\
\hline $\mathrm{Ca}_{\text {total }}$ & 2.09 & 0.34 & 34 & +0.07 & 0.31 & n.s. \\
\hline $\mathrm{iNa}^{+}$ & 139.37 & 3.96 & 36 & +0.04 & 2.15 & n.s. \\
\hline $\mathrm{iK}^{+}$ & 4.30 & 0.79 & 28 & +0.07 & 0.81 & n.s. \\
\hline $\begin{array}{l}\text { Free fatty } \\
\text { acids }\end{array}$ & 2.32 & 1.81 & 30 & -0.69 & 1.16 & $* *$ \\
\hline
\end{tabular}

Levels of significance:

$\begin{array}{ll}*: & \mathrm{p}<0.05 \\ * *: & \mathrm{p}<0.01 \\ * * *: & \mathrm{p}<0.001 \\ \mathrm{n} . \mathrm{s.:} & \text { non-significant } \\ \mathrm{n}: & \text { number of acute myocardial infarction patients } \\ \mathrm{iMg}{ }^{2+}: & \text { ionized free serum magnesium } \\ \mathrm{Mg}_{\text {total }}: & \text { total serum magnesium } \\ \mathrm{iCa}^{2+}: & \text { ionized free serum calcium } \\ \mathrm{Ca}_{\text {total }}: & \text { total serum calcium } \\ \mathrm{iNa}^{+}: & \text {ionized free serum sodium } \\ \mathrm{iK}^{+}: & \text {ionized free serum potassium }\end{array}$

Tab. 2 Rank correlation coefficients ( $r$ ) between each analysis at day 1 and day 2 of acute myocardial infarction.

$\mathrm{Mg}_{\text {total }}, \mathrm{iMg}^{2+}, \mathrm{Ca}_{\text {total }}, \mathrm{iCa}^{2+}, \mathrm{iK}^{+}, \mathrm{iNa}^{+}$, free fatty acid concentrations in serum at day 1 or day 2.

\begin{tabular}{llll}
\hline Analyses & & & \\
\hline Day 1 & Day 2 & $\mathrm{r}$ & $\mathrm{n}$ \\
\hline $\mathrm{Mg}_{\text {total }}$ & $\mathrm{Mg}_{\text {total }}$ & 0.54 & $36 *$ \\
$\mathrm{iMg}^{2+}$ & $\mathrm{iMg}^{2+}$ & 0.08 & 36 n.s. \\
$\mathrm{Ca}_{\text {total }}$ & $\mathrm{Ca}_{\text {total }}$ & 0.40 & $36 *$ \\
$\mathrm{iCa}^{2+}$ & $\mathrm{iCa}^{2+}$ & 0.24 & 36 n. s. \\
$\mathrm{iK}^{+}$ & $\mathrm{iK}^{+}$ & 0.41 & $28 *$ \\
iNa & $\mathrm{iNa}^{+}$ & 0.84 & $36 * * *$ \\
Free fatty acids & Free fatty acids & 0.55 & $31^{*}$ \\
\hline
\end{tabular}

For significance see legend of table 1 .

Tab. 3 Rank correlations coefficients ( $r$ ) between differences of analyses at day 1 and day 2 of acute myocardial infarction. e. $\mathrm{g} .:\left[\Delta \mathrm{iMg}^{2+}=\mathrm{iMg}_{2}^{2+}-\mathrm{iMg}_{1}^{2+}\right]$

\begin{tabular}{llrl}
\hline Analyses & & $\mathrm{r}$ & $\mathrm{n}$ \\
\hline$\Delta \mathrm{iMg}^{2+}$ & $\Delta \mathrm{Mg}_{\text {total }}$ & 0.77 & $36 * *$ \\
$\Delta \mathrm{iMg}^{2+}$ & $\Delta \mathrm{iK}^{+}$ & 0.45 & $28 *$ \\
$\Delta \mathrm{iMg}^{2+}$ & $\Delta \mathrm{iNa}^{+}$ & -0.37 & $36 *$ \\
$\Delta \mathrm{Mg}^{+}$ & $\Delta \mathrm{iK}^{+}$ & 0.46 & $28 *$ \\
$\Delta \mathrm{iK}^{+}$ & $\Delta \mathrm{iNa}^{+}$ & -0.37 & $28 *$ \\
\hline
\end{tabular}

For significance see legend of table 1.

other electrolytes did not change significantly from day 1 to day 2 . These results show that $\mathrm{iMg}^{2+}$ changes much more from day 1 to 2 after acute myocardial infarction than $\mathrm{Mg}_{\text {total }}$.

Table 2 presents the rank correlation coefficients of each electrolyte species and free fatty acid concentration between day 1 and day 2 . The high correlation coefficient $(r=0.84)$ between serum $\mathrm{Na}^{+}$concentration at day 1 $\left(\mathrm{iNa}_{1}^{+}\right)$and day $2\left(\mathrm{iNa}_{2}^{+}\right)$indicates that the sodium concentration in serum does not change significantly after acute myocardial infarction. The concentration of serum potassium from day 1 to day 2 is less constant $(r=0.41)$ and the ionized fractions of $\mathrm{Ca}^{2+}(\mathrm{r}=0.24)$ and $\mathrm{Mg}^{2+}$ $(r=0.08)$ are not even significantly correlated between day 1 and day 2 while $\mathrm{Mg}_{\text {total }}(\mathrm{r}=0.54)$ and $\mathrm{Ca}_{\text {total }}$ $(r=0.40)$ are significantly correlated. These results show that the individual changes of $\mathrm{iMg}^{2+}$ and $\mathrm{iCa}^{2+}$ from day 1 to day 2 after acute myocardial infarction are more pronounced than the individual changes of $\mathrm{Mg}_{\text {total }}$ and $\mathrm{Ca}_{\text {total }}$.

In table 3 the rank correlation coefficients of all significant correlations between changes of different electrolyte species and free fatty acids are listed. The correlation between the changes of $\mathrm{iMg}^{2+}$ and $\mathrm{iK}^{+}(\mathrm{r}=0.45)$ from day 1 to 2 indicate that potassium and magnesium are concordantly affected. This is also shown by a plot 
of the two analytes together with a linear regression (fig. 1). This result may be of clinical importance (see Discussion). The differences of $\mathrm{iNa}^{+}$are negatively correlated both with the differences of $\mathrm{iMg}^{2+}(\mathrm{r}=-0.37)$ and of $\mathrm{iK}^{+}(\mathrm{r}=-0.37)$.

It is important to note that there existed no significant correlation between the changes of $\mathrm{iMg}^{2+}$ and the free fatty acids during the first two days after the acute myocardial infarction. We therefore investigated whether such a correlation existed in the sub-group with the strongest relative decrease of $\mathrm{iMg}^{2+}$ on the day of the acute myocardial infarction. For this purpose the distribution of the relative changes of $\mathrm{iMg}^{2+}$ from day 1 to day 2 is shown in figure 2 . As indicated in figure 2 the patients were divided into three sub-groups with 12 patients each according to the relative changes of their $\mathrm{iMg}^{2+}$ from day 1 to day 2 . Thus, in sub-group $\mathrm{A} \mathrm{iMg}^{2+}$ was lower at day 1 by $-11.5 \%$ to $-32 \%$. In sub-group $\mathrm{B}$ on the other hand $\mathrm{iMg}^{2+}$ was higher by $+1 \%$ to $+20 \%$. Between these two sub-groups lies a sub-group with changes of $\mathrm{iMg}^{2+}$ by $-11 \%$ to $0 \%$.

Time courses of $\mathrm{iMg}^{2+}, \mathrm{Mg}_{\text {total }}, \mathrm{iK}^{+}$and free fatty acids were plotted for sub-groups $A$ and $B$ (see figs 3-6). In the patients of sub-group $A$ at the day of infarction $\mathrm{iMg}^{2+}$ (fig. 3 a), $\mathrm{Mg}_{\text {total }}$ (fig. $4 \mathrm{a}$ ) and $\mathrm{iK}^{+}$(fig. $5 \mathrm{a}$ ) were low, increased to day 2 and remained almost constant thereafter. In these patients free fatty acids (fig. 6 a) were highest at day 1 and decreased thereafter.

In patients of sub-group $B$, who were selected by their high $\mathrm{iMg}^{2+}$ at day $1, \mathrm{Mg}_{\text {total }}$ and $\mathrm{iK}^{+}$were also highest at day 1 and decreased later. Free fatty acids remained almost constant throughout day 1 to day 7 (fig. $3 \mathrm{~b}, 4 \mathrm{~b}$,

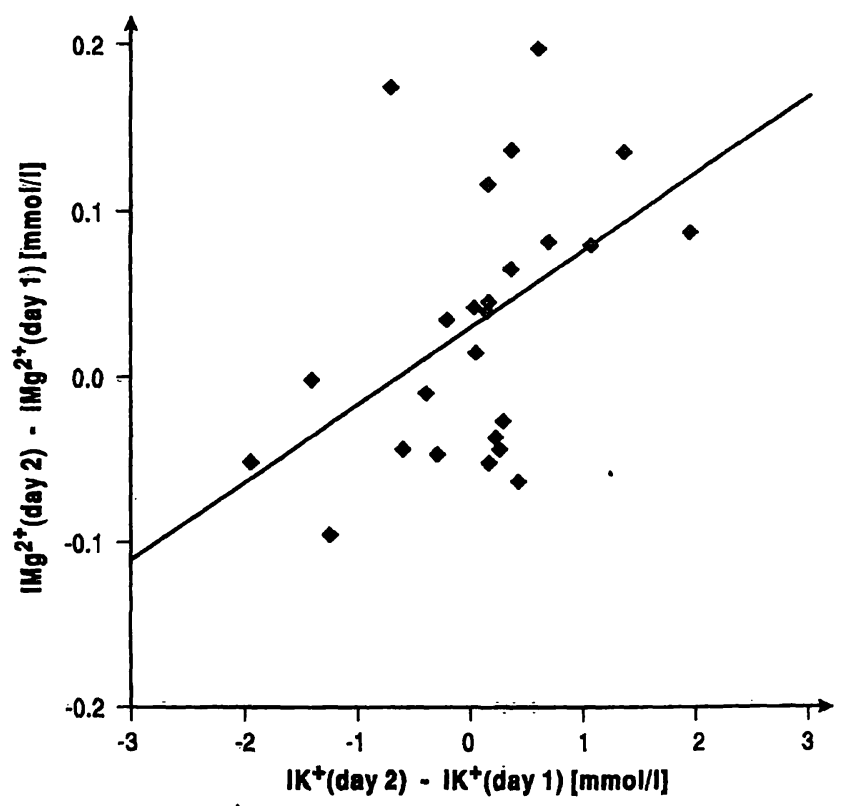

Fig. 1 Scatter plot of the differences of $\mathrm{iMg}^{2+}$ versus the differences of $\mathrm{iK}^{+}$from day 1 to day 2 of acute myocardial infarction.

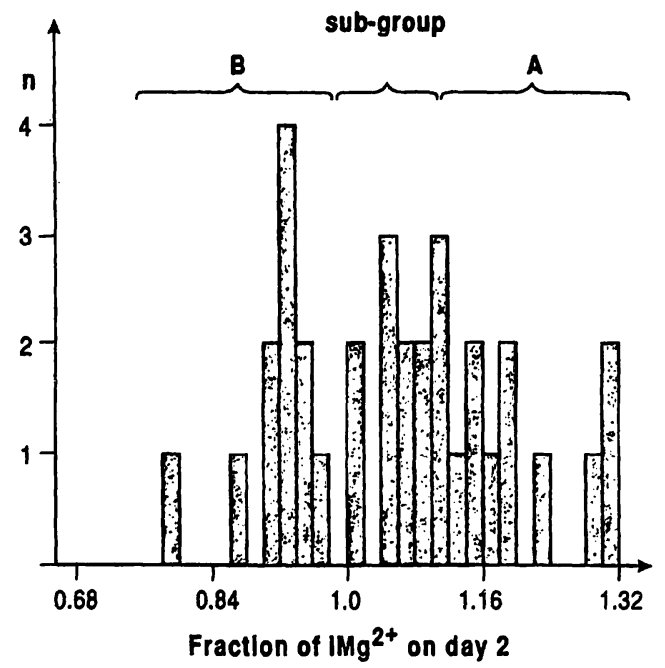

Fig. 2 Distribution of fractions of $\mathrm{iMg}^{2+}$ on day 2 after myocardial infarction: $\left(\mathrm{iMg}_{2}^{2+}-\mathrm{iMg}_{1}^{2+}\right) / \mathrm{iMg}_{2}^{2+} . \mathrm{n}$ : numbers of patients with given fractions of $\mathrm{iMg}^{2+}$ at day 2 . A: sub-group of 12 patients with lowest $\mathrm{iMg}^{2+}, \mathrm{B}$ : sub-group of 12 patients with highest $\mathrm{iMg}^{2+}$ at day of infarction.

$5 \mathrm{~b}, 6 \mathrm{~b})$. Time courses of $\mathrm{iCa}^{2+}, \mathrm{Ca}_{\text {total }}$ and $\mathrm{iNa}^{+}$are not shown, since their changes with time as well as their differences between sub-groups were not significant.

\section{Discussion}

Low $\mathrm{iMg}^{2+}$ was observed at the day of infarction in the total group of myocardial infarction patients. A more thorough analysis showed that acute myocardial infarction patients did not behave homogeneously with respect to $\mathrm{iMg}^{2+}, \mathrm{Mg}_{\text {total }}, \mathrm{iK}^{+}$and free fatty acids. Therefore, the acute myocardial infarction patients were divided into 3 sub-groups according to their relative changes of $\mathrm{iMg}^{2+}$ from day 1 to day 2 .

Sub-group A consisted of patients with the strongest increases of $\mathrm{iMg}^{2+}$ from day 1 to day 2 . In this sub-group $\mathrm{Mg}_{\text {total }}$ and $\mathrm{iMg}^{2+}$ in serum were low immediately after acute myocardial infarction (day 1 ) and $\mathrm{iMg}^{2+}$ reached normal values at day 2 . The changes of $\mathrm{iK}^{+}$are closely correlated to the changes of $\mathrm{iMg}^{2+}$. A close relationship was also shown for total $\mathrm{Mg}$ and $\mathrm{iK}^{+}$in serum (19).

The behaviour of total serum $\mathrm{Mg}$ is in accordance with earlier results (19-23), which showed that the low total serum $\mathrm{Mg}$ after acute myocardial infarction normalized during the following few days. In the present study we additionally measured $\mathrm{iMg}^{2+}$ and found that in the patients of sub-group $\mathrm{A}, \mathrm{iMg}^{2+}$ at the day of acute myocardial infarction was much more reduced than total $\mathrm{Mg}$. This result can be explained by the time course of free fatty acids in serum. At day 1 of acute myocardial infarction, free fatty acids were increased. This is probably caused by $\beta$-adrenergic-induced lipolysis due to catecholamines released by the stressful situation of acute 

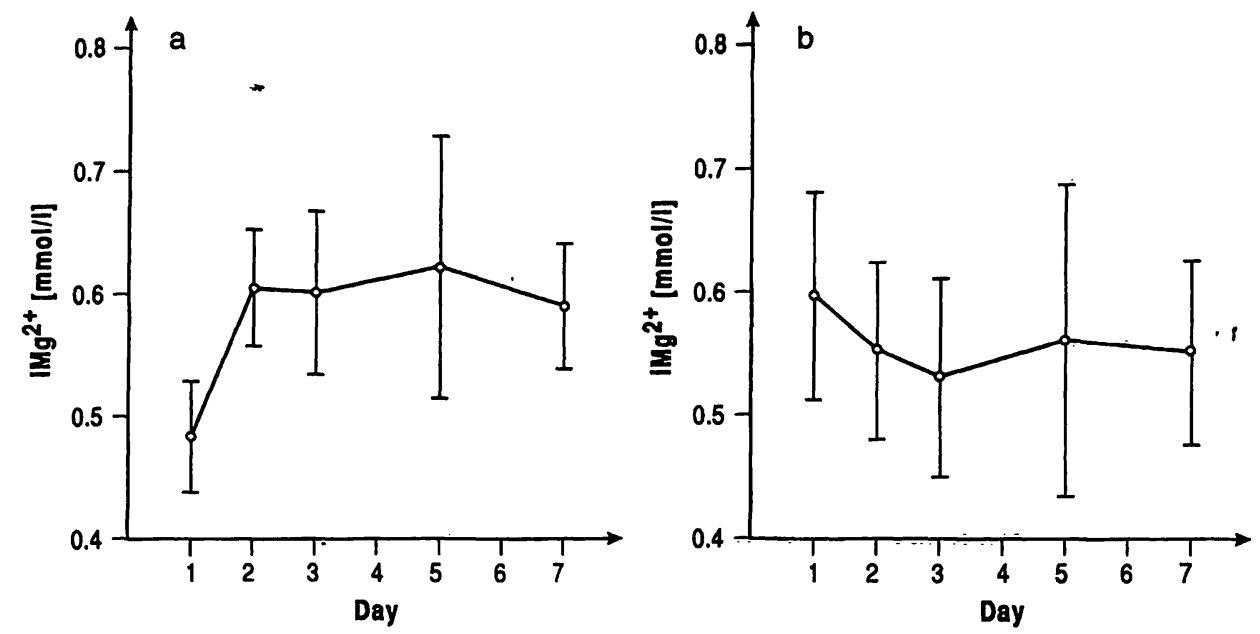

Fig. 3 Time courses of $\mathrm{Mg}^{2+}$ concentration in serum of acute myocardial infarction patients: sub-group $A(a)$ and sub-group $B(b)$. Mean values \pm SD.
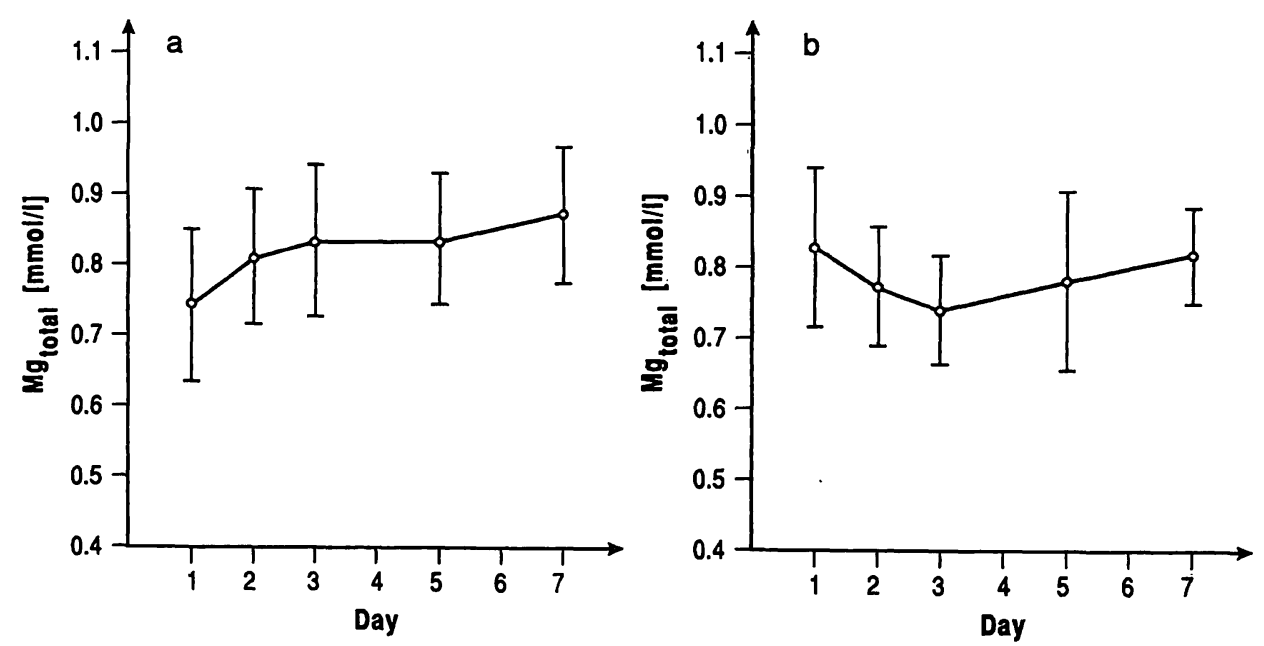

Fig. 4 Time courses of $\mathrm{Mg}_{\text {total }}$ concentration in serum of acute myocardial infarction patients: sub-group $A(a)$ and sub-group $B(b)$. Mean values $\pm S D$.

myocardial infarction $(4,28)$. The increased free fatty acids in serum bind $\mathrm{Mg}^{2+}$ and $\mathrm{Ca}^{2+}$, thus reducing $\mathrm{iMg}^{2+} . \mathrm{iCa}^{2+}$ may not be reduced since it can be rapidly regulated by parathormone.

The transient reduction of total serum $\mathrm{Mg}$ can be explained by a transient uptake of extracellular $\mathrm{Mg}^{2+}$ by adipocytes $(24,25)$. Catecholamines increase lipolysis in adipocytes. The released free fatty acids in adipocytes bind intracellular $\mathrm{Mg}^{2+}$ and thus reduce intracellular free $\mathrm{Mg}^{2+}$ in the adipocytes. This is followed by uptake of extracellular $\mathrm{Mg}^{2+}$ by adipocytes (25), resulting in a reduction of total serum $\mathrm{Mg}$.

Our findings may have clinical consequences. We suggest that only acute myocardial infarction patients with decreased $\mathrm{iMg}^{2+}$ and $\mathrm{iK}^{+}$should be infused with $\mathrm{Mg}^{2+}$. In the case of reduced $\mathrm{iK}^{+}, \mathrm{K}^{+}$infusion is common clinical practice. However, in two major clinical studies LIMIT $2(29-31)$ and ISIS $4(32,35)$ and in 12 small trials controversial effects of $\mathrm{Mg}^{2+}$ infusions in acute myocardial infarct patients were found and in a few meta-analyses the controversial results were discussed. For a review of the literature see 1.c. (36).

While LIMIT 2 (29-31) found positive effects, this was not confirmed in ISIS $4(32,35)$. The missing beneficial effect of ISIS 4 was explained and experimentally proven by the late time point of $\mathrm{Mg}^{2+}$ infusion, e.g. after lysis (33). It was also suggested that the high $\mathrm{Mg}^{2+}$ dose used in ISIS 4 may have produced negative side effects (34).

As long as it remains controversial whether a general $\mathrm{Mg}^{2+}$ infusion of all acute myocardial infarction patients is beneficial, we suggest that $\mathrm{iMg}^{2+}$ should be measured and $\mathrm{Mg}^{2+}$ should be infused only in acute myocardial infarction patients with low $\mathrm{iMg}^{2+}$. Since in most hospitals the equipment for $\mathrm{iMg}^{2+}$ estimation is not available, hypokalaemia may be taken as indication for low $\mathrm{iMg}^{2+}$. This compromise can be justified by the significant correlation between the changes of $\mathrm{iK}^{+}$and 

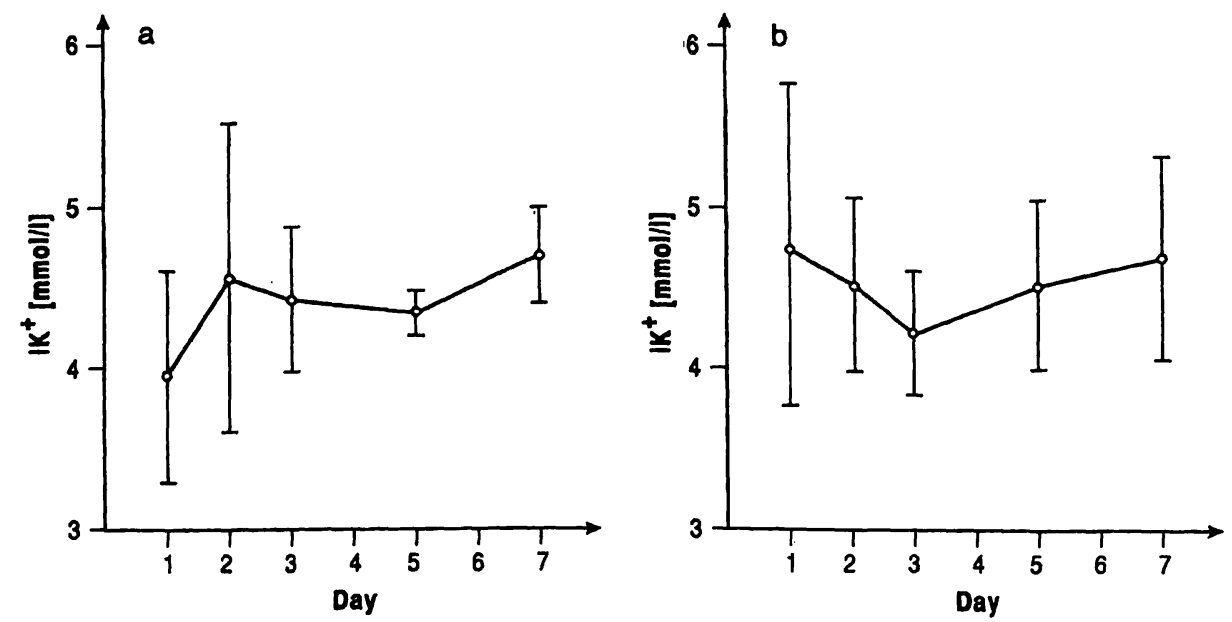

Fig. 5 Time courses of $\mathrm{iK}^{+}$concentration in serum of acute myocardial infarction patients: sub-group $A(a)$ and sub-group $B(b)$. Mean values $\pm S D$.
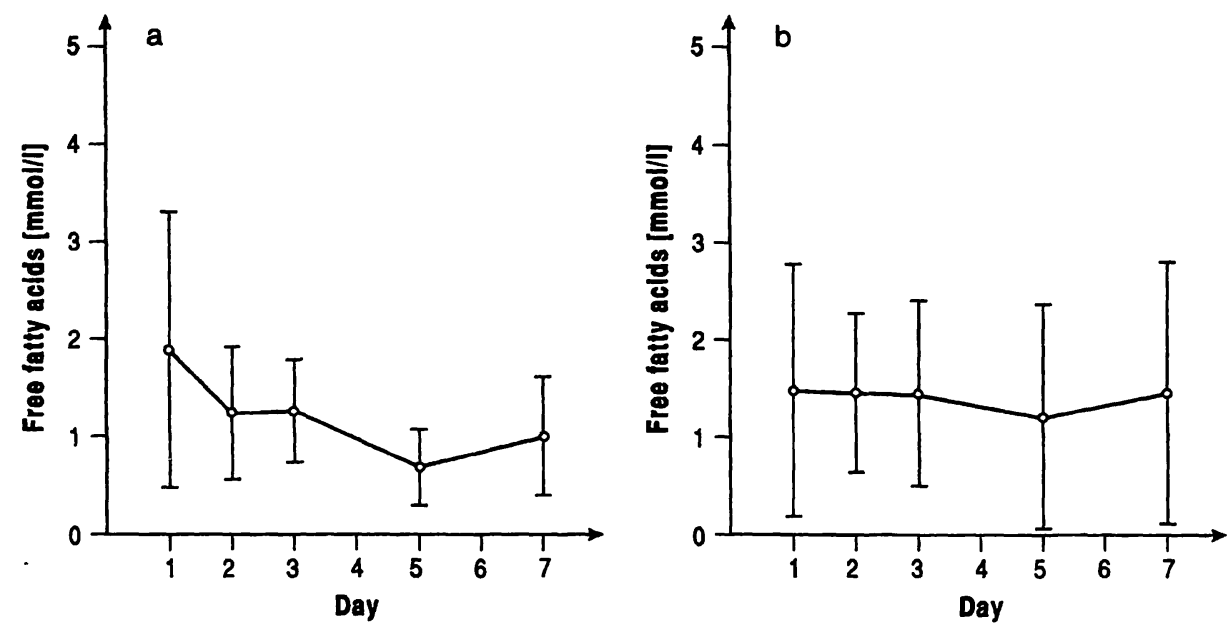

Fig. 6 Time courses of free fatty acid concentration in serum of acute myocardial infarction patients: sub-group $A(a)$ and sub-group $B(b)$. Mean values $\pm S D$.

$\mathrm{iMg}^{2+}$ after acute myocardial infarction. However, as figure 1 shows, this compromise is by far not optimal. Therefore, $\mathrm{iMg}^{2+}$ measurements should be installed as clinical routine for acute myocardial infarction patients.

\section{References}

1. Wolfe CL, Nibley C, Bhandari A, Chatterjee K, Scheinman M. Polymorphous ventricular tachycardia associated with acute myocardial infarction. Circulation 1991; 84:1543-51.

2. Brugada P, Andries EW, Gursoy S, Willems H, Kaissar S. Mechanisms of sudden cardiac death. Drugs 1991; 41 Suppl 2:16-23

3. Späth G. Torsade de pointes oder die andere Ursache des plötzlichen Herztodes. Wien, Berlin, Ueberreuter Wissenschaftsverlag G.m.b.H., 1988.

4. Ceremuzynski L. Hormonal and metabolic reactions evoked by acute myocardial infarction. Circ Res 1981; 48:767-76.

5. Dyckner T, Wester PO. Relation between potassium, magnesium and cardiac arrhythmias. Acta Med Scand 1981; Suppl 647:163-9.
Since reduction of $\mathrm{iMg}^{2+}$ can increase the release of catecholamines (13) and in cooperation with catecholamines may intensify cardiac arrhythmia (4), $\mathrm{Mg}^{2+}$ infusion should be an additional beneficial treatment of acute myocardial infarction patients with low $\mathrm{iMg}^{2+}$.

6. Kafka H, Langevin L, Armstrong PW. Serum magnesium and potassium in acute myocardial infarction. Influence on ventricular arrhythmias. Arch Intern Med 1987; 147:465-9.

7. Havestadt C, Ising H, Günther T, Feldmann B, Schlüter HJ. Electrolytes and ventricular arrhythmias. Magnesium 1985; $4: 29-33$

8. Joborn H, Hjemdahl P, Larsson PT, Lithell H, Olsson G, Wiede $L$, et al. Effects of prolonged adrenaline infusion and of mental stress on plasma minerals and parathyroid hormone. Clin Physiol 1990; 10:37-53.

9. Flink EB, Brick JE, Shane SR. Alterations of long-chain free fatty acid and magnesium concentrations in acute myocardial infarction. Arch Intern Med 1981; 141:441-4. 
10. Solomon RJ. Ventricular arrhythmias in patients with myocardial infarction and ischemia. Relationship to serum potassium and magnesium. Drugs 1984; 28 Suppl 1:66-75.

11. Tosaki A, Das DK. Reperfusion induced arrhythmias are caused by generation of free radicals. Cardiovasc Res 1994; 28:422.

12. Euler DE. Reperfusion induced arrhythmias are not caused by generation of free radicals. Cardiovasc Res 1994; 28:423.

13. Günther T, Ising H, Merker HJ. Elektrolyt- und Kollagengehalt im Rattenherz bei chronischem Magnesium-Mangel und Streß. J Clin Chem Clin Biochem 1978; 16:293-7.

14. Günther T. Biochemistry and pathobiochemistry of magnesium. Mag Bull 1981; 3:91-101.

15. Günther T, Vormann J, Höllriegl V, Disch G, Classen HG. Role of lipid peroxidation and vitamin $E$ in magnesium deficiency. Mag Bull 1992; 14:57-66.

16. Dyckner $T$, Helmers $C$, Lundmann $T$, Wester PO. Initial serum potassium level in relation to early complications and prognosis in patients with acute myocardial infarction. Acta Med Scand 1975; 197:207-10.

17. Bigg RPC, Chia R. Magnesium deficiency: role in arrhythmias complicating myocardial infarction. Med J Austral 1981; 1:346-8.

18. Iseri LT, Freed J, Bures AR. Magnesium deficiency and cardiac disorders. Am J Med 1975; 58:837-46.

19. Landmark $K$, Urdal $P$, Basmo GM. Changes in serum $K$ and $\mathrm{Mg}$ during acute myocardial infarction [abstract]. Eur Heart $\mathrm{J}$ 1988; 9 Suppl 1:227, 1260.

20. Ising H, Günther T, Bertschat F, Ibe K, Stoboy V, Heldmann E. Alterations of electrolytes in serum and erythrocytes after myocardial infarction. Magnesium 1987; 6:192-200.

21. Chadda KD. Serum, red cell and whole blood magnesium in patients with uncomplicated acute myocardial infarction. Magnesium 1986; 5:76-84.

22. Rasmussen HS, Aurop P, Hojberg S, Kehn-Jensen E, McNair $P$. Magnesium and acute myocardial infarction. Transient hypomagnesemia not induced by renal magnesium loss in patients with acute myocardial infarction. Arch Intern Med $1986 ; 146: 872-4$.

23. Tsutsui M, Shimokawa H, Yoshihara S, Sobashima A, Hayashida $\mathrm{K}$, Higuchi $\mathrm{S}$, et al. Intracellular magnesium deficiency in acute myocardial infarction. Jap Heart J 1993; 34:391-401.

24. Elliott DA, Rizack MA. Epinephrine and adrenocorticotropic hormone-stimulated magnesium accumulation in adipocytes and their plasma membranes. J Biol Chem 1974; 249:398590 .
25. Vormann J, Förster R, Günther T, Ebel H. Lipolysis-indụced magnesium uptake into fat cells. Mag Bull 1983; 5:39-41.

26. Ising $H$, Bertschat $F$, Günther $T$, Jeremias $E$, Jeremias $A$. Measurement of free magnesium in blood, serum and plasma with an ion-sensitive electrode. Eur J Clin Chem Clin Biochem 1995; 33:365-71.

27. Mulder C, Schonten JA, Popp-Snijders C. Determination of free fatty acids. A comparative study of the enzymatic versus the gaschromatographic and the colorimetric method. J Clin Chem Clin Biochem 1983; 21:823-7.

28. Hansen O, Johansson BW. S-Mg does not change inversely to S-FFA during acute stress situations. Angiology 1989; 11:1011-8.

29. Woods $\mathrm{KL}$, Fletcher S, Roffe C, Haider Y. Intravenous magnesium sulphate in suspected acute myocardial infarction: results of the second Leicester Intravenous Magnesium Intervention Trial (LIMIT-2). Lancet 1992; 339:1553-8.

30. Yusuf $\mathrm{S}$, Teo $\mathrm{K}$, Woods $\mathrm{K}$. Intravenous magnesium in acute myocardial infarction. An effective, safe, simple, and inexpensive intervention. Circulation 1993; 876:2043-6.

31. Millane TA, Camm AJ. Magnesium and the myocardium. Brit Heart J 1992; 68:441-2.

32. Cascells W. Magnesium and myocardial infarction. Lancet 1994; 343:807-9.

33. Atar D, Serebruany V, Poulton J, Godard J, Schneider A, Herzog WR. Effects of magnesium supplementation in a porcine model of myocardial ischemia and reperfusion. $\mathrm{J}$ Cardiovasc Pharmacol 1994; 24:603-11.

34. Galloe A, Graudal N. Magnesium and myocardial infarction. Lancet $1994 ; 343: 1286-7$.

35. ISIS-4 (Fourth International Study of Infarct Survival) Collaborative Group ISIS-4: A randomised factorial trial assessing early oral captopril, oral mononitrate, and intravenous magnesium sulphate in 58050 patients with suspected acute myocardial infarction. Lancet 1995; 345:669-85.

36. Egger $\mathrm{M}$, Smith G. Misleading meta-analysis. Br Med J 1995; 310:752-4.

Priv. Doz. Dr. med. Frank Bertschat

Virchow Klinikum

der Humboldt Universität zu Berlin

Med. Klinik und Poliklinik mit

Schwerpunkt Nephrologie/Intensivmedizin

Augustenburger Platz 1

13353 Berlin

Germany 